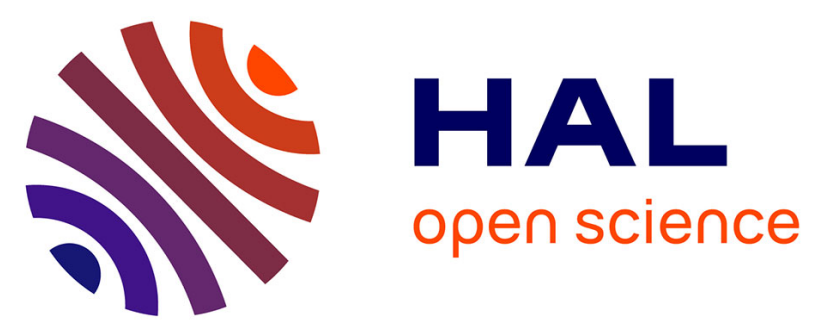

\title{
Cephalopod beak sections used to trace mercury levels throughout the life of cephalopods: the Giant Warty squid Moroteuthopsis longimana as a case study
}

José Queirós, Paco Bustamante, Yves Cherel, Joao Coelho, José Seco, Jim Roberts, Eduarda Pereira, José Xavier

\section{To cite this version:}

José Queirós, Paco Bustamante, Yves Cherel, Joao Coelho, José Seco, et al.. Cephalopod beak sections used to trace mercury levels throughout the life of cephalopods: the Giant Warty squid Moroteuthopsis longimana as a case study. Marine Environmental Research, 2020, 161, pp.105049. 10.1016/j.marenvres.2020.105049 . hal-02904190

\section{HAL Id: hal-02904190 \\ https://hal.science/hal-02904190}

Submitted on 21 Jul 2020

HAL is a multi-disciplinary open access archive for the deposit and dissemination of scientific research documents, whether they are published or not. The documents may come from teaching and research institutions in France or abroad, or from public or private research centers.
L'archive ouverte pluridisciplinaire HAL, est destinée au dépôt et à la diffusion de documents scientifiques de niveau recherche, publiés ou non, émanant des établissements d'enseignement et de recherche français ou étrangers, des laboratoires publics ou privés. 


\section{Cephalopod beak sections used to trace mercury levels}

\section{throughout the life of cephalopods: the Giant Warty squid}

\section{Moroteuthopsis longimana as a case study}

José P. Queirós*a, Paco Bustamante ${ }^{\mathrm{b}, \mathrm{c}}$, Yves Cherel ${ }^{\mathrm{d}}$, João P. Coelho ${ }^{\mathrm{e}}$, José Secof,g, Jim Roberts ${ }^{\text {h }}$, Eduarda Pereiraf ${ }^{\text {\& José C. Xavier }}{ }^{a, i}$

a - University of Coimbra, MARE - Marine and Environmental Sciences Centre, Department of Life Sciences, 3000-456, Coimbra, Portugal

b - Littoral Environnement et Sociétés (LIENSs), UMR 7266 CNRS-La Rochelle Université, 2 rue Olympe de Gouges, 17000 La Rochelle, France

c - Institut Universitaire de France (IUF), 1 rue Descartes 75005 Paris, France

d - Centre d'Etudes Biologiques de Chizé, UMR 7372 du CNRS-La Rochelle Université, 79360 Villiers-en-Bois, France.

E - Departamento de Biologia \& CESAM, - Centro de Estudos do Ambiente e do Mar, Universidade de Aveiro, Campus Universitário de Santiago, 3810-193 Aveiro, Portugal

f - Departamento de Química \& CESAM - Centro de Estudos do Ambiente e do Mar, Universidade de Aveiro, Campus Universitário de Santiago, 3810-193 Aveiro, Portugal

g - Pelagic Ecology Research Group, Scottish Oceans Institute, University of St Andrews, St Andrews KY16 8LB, United Kingdom

h - NIWA - National Institute for Water and Atmospheric Research, 301 Evans Bay Parade, Hataitai, Wellington 6021, New Zealand

i - British Antarctic Survey, NERC, High Cross, Madingley Road, CB3 0ET, Cambridge, UK.

*Corresponding Author: josequeiros@ua.pt 
Abstract: Cephalopods represent an important pathway for mercury transfer through food-webs. Due to the general difficulties in capturing oceanic squid, beaks found in the diet of top predators can be used to study their life-cycles and ecological role. Using upper beaks of the giant warty squid Moroteuthopsis longimana (major prey in the Southern Ocean), we describe a method to assess mercury concentrations along the life of cephalopods through the segmentary analysis of beak sections (i.e. rostrum's tip and subsections along the hood). Distinct total mercury concentrations in the different subsections support that beaks can be used to study mercury levels in different periods of cephalopods' life-cycle. Mercury values in the anterior (1.3 to $7.9 \mu \mathrm{g} \mathrm{kg}^{-1} \mathrm{dw}$ ) and posterior (7.8 to $12.5 \mu \mathrm{g} \mathrm{kg} \mathrm{kg}^{-1} \mathrm{dw}$ ) subsections reflect juvenile and adult stages, respectively. Furthermore, these results confirm that mercury bioaccumulates continuously throughout the individuals' life, with adults doubling their mercury concentrations to juveniles.

Keywords: Mercury, Trace elements, Southern Ocean, Ontogenetic shifts, Bioaccumulation 


\section{Introduction}

Occurring naturally in the World's Ocean, e.g. via emissions from hydrothermal vents (Mason et al., 2012), mercury is a contaminant that presents high toxicity to animals, including humans (Karagas et al., 2012; Mason et al., 2012; Wolfe et al., 1998). Primarily found in its inorganic forms $\left(\mathrm{Hg}^{\mathrm{II}}\right)$, the activity of anaerobic bacteria or the decomposition of organic carbon transforms it in methylmercury $\left(\mathrm{CH}_{3} \mathrm{Hg}\right)$ (Mason et al., 2012). In its methylated form, mercury bioaccumulates in marine organisms and biomagnifies through food webs (Jarman et al., 1996; Mason et al., 2012; Penicaud et al., 2017). Mercury concentrations in marine ecosystems increased over the last decades due to anthropogenic activities (Mason et al., 2012; Streets et al., 2011), with climate change exacerbating this increase by, for example, releasing the mercury trapped in melting glaciers (Eagles-Smith et al., 2018; Stern et al., 2012). The Southern Ocean is one of the World's oceans with highest mercury levels, with the percentage of methylated mercury varying between waters south ( $74 \%$ of the total mercury) and north ( $\sim 50 \%$ of the total mercury in deep waters) of the Antarctic Polar front (Cossa et al., 2011; Mason et al., 2012), with top predators already presenting high levels of mercury (Carravieri et al., 2016; Cherel et al., 2018; Tavares et al., 2013). Mainly transmitted by the food web, prey is the main source of mercury to top predators (Anderson et al., 2009; Seco et al., 2019).

Cephalopods have a major ecological and economical relevance in marine ecosystems around the world, being both predator and prey in food webs (Boyle and Rodhouse, 2005; Young et al., 2013). Because cephalopods are abundant and are known to accumulate considerable levels of mercury in their tissues (Bustamante et al., 2006; Seco et al., 2020), they play an important role in the transfer of mercury to the top of food webs (Bustamante et al., 2006; Xavier et al., 2018; Young et al., 2013). Until now, numerous studies assessed mercury levels in the digestive gland of cephalopods. The 
metal detoxification capacities of this organ are well-known (Penicaud et al., 2017). Together with mercury levels in muscle (e.g. mantle and arms), these tissues may contain up to $90 \%$ of the whole mercury body burden (Bustamante et al., 2006). Muscle are also the most consumed tissue by predators and represent the main pathway for mercury transfer (Bustamante et al., 2006; Chouvelon et al., 2012; Pierce et al., 2008). However, the study of both digestive gland and muscle was carried out mostly for coastal and commercialised species (Bustamante et al., 2006; Chouvelon et al., 2012; Lourenço et al., 2009; Pierce et al., 2008), mainly because traditional fishing methods generally do not capture non-commercialised species (Boyle and Rodhouse, 2005). Moreover, with the low number of scientific cruises targeting cephalopods in remote areas of the world, e.g. the Southern Ocean (Griffiths, 2010), a gap of knowledge persists regarding the mercury levels of Antarctic oceanic squid (Rodhouse et al., 2014).

Cephalopod beaks (chitinous mandibles) growth throughout the life of individuals without replacement and are widely used in cephalopod studies (Clarke, 1986; Xavier and Cherel, 2009; Xavier et al., 2016). Beaks resist to digestion and accumulate in predators' stomachs (Clarke, 1986; Miserez et al., 2010; Tan et al., 2015), which can be easily accessed for research studies through different methods (Xavier \& Cherel, 2009). Different analyses applied to beaks (e.g. stable isotopes) allow the study of several characteristics of the squid's life-cycle, including habitat, trophic ecology, age and life events (Cherel and Hobson, 2005; Perales-Raya et al., 2010, 2014, 2018; Ruiz-Cooley et al., 2006). Recently, Xavier et al. (2016a) also showed that beaks can be used to access mercury levels in cephalopods. Despite beaks are not the major mercury accumulator in cephalopods, their concentration can be used as a proxy for other tissues [e.g. muscle possesses approx. 10-fold more mercury than beaks (Matias et al., 2019; Xavier et al., 2016a)]. Yet, as in digestive gland and muscle analyses, mercury determination using 
whole beaks provide only an average of individuals' levels, while it is known that some species shift their diet and/or habitat with ontogenesis (Chouvelon et al., 2011). Recent studies showed that the analysis of different beak regions provided valuable data on different periods of individuals' lifespans, from juvenile to adult stages (Guerra et al., 2010; Queirós et al., 2018). The evolution of the trophic position revealed by the analysis of different portions of squid beaks, suggests that the mercury exposure of squids evolves during ontogenesis, as shown for soft tissues (Chouvelon et al., 2011). Thus, there is a need to develop a simple technique that, using squid beaks, enables to study the variation of mercury exposure in different periods of an individuals' life.

Within Antarctic squid, the giant warty squid Moroteuthopsis (formerly known as Kondakovia) longimana [Family: Onychoteuthidae (Bolstad et al., 2018)], is a Southern Ocean squid with a circumpolar distribution (Xavier et al., 2016b), which can be used as a model species to develop such method. M. longimana is predated in different stages of its life-cycle (e.g. penguins feed on juveniles whilst wandering albatrosses/toothfish/toothed whales feed on adults (Cherel and Weimerskirch, 1999; Roberts et al., 2011; Xavier et al., 2003) and exhibits a large size and mass [mantle length up to 1.1 m (Lynnes and Rodhouse, 2002; Rodhouse et al., 2014)]. Due to its importance in the diet of Antarctic top predators, M. longimana can be an important pathway of mercury through the Antarctic food web, thus it is also important to assess mercury levels along its life. Furthermore, ontogenetic changes in the diet throughout the life cycle of $M$. longimana (Cherel and Hobson, 2005; Queirós et al., 2018) suggest a change in the mercury exposure because of mercury trophic-magnification (Chouvelon et al., 2011; Jarman et al., 1996). This change in exposure confirms M. longimana as a good model organism to validate this technique since it allows to determine which beak sections 
provide reliable values for the different life-stages. Also, its large beaks provide more material to test this methodology, as are easier to sectioning.

Under such context, habitat and trophic ecology ( $\delta^{13} \mathrm{C}$ and $\delta^{15} \mathrm{~N}$ values $)$ of upper cephalopod beaks have been already analysed from the tip of the rostrum (proxy for early life-stage) and four subsections along the hood (posterior region of the hood represents older life-stage) to discriminate different periods of the life-cycle of $M$. Longimana specimens used in this study (Queirós et al., 2018). Here, the main objectives are: (1) to describe a reliable method to study mercury levels throughout an individuals' life-cycle using different sections of upper beaks; and (2) to compare the mercury levels in different M. longimana's life stages with its respective habitat and trophic ecology.

\section{Materials \& Methods}

Beaks of M. longimana were collected from different stomachs of Patagonian toothfish Dissostichus eleginoides captured in 2009 on board of the FV San Aspiring at South Sandwich Islands [between 55.7 $\mathrm{S}$ and 59.9 ${ }^{\circ} \mathrm{S}$ (Roberts et al., 2011)]. Beaks were identified following Xavier and Cherel (2009) and preserved in 70\% ethanol.

A total of 10 large upper beaks previously analysed for $\delta^{13} \mathrm{C}$ and $\delta^{15} \mathrm{~N}$ (Queirós et al. 2018) were used in this study. All these beaks had similar size and belonged to adult individuals of M. longimana (fully chitinized beaks (Clarke, 1986), and the Upper Hood Length (UHL) measured using a digital calliper $( \pm 0.01 \mathrm{~mm})$ (Table 1, Fig. 1). For stable isotopic analysis and mercury analyses (see below), these beaks were sectioned using laboratory stainless steel scissors into tip of the rostrum $(\mathrm{R})$ and a section along the hood, afterwards subdivided into four equal subsections - IV the earliest and I the latest to be formed (Fig. 1). To cut the tip of the rostrum, we started by doing a mark (using the scissors) in the zone where we were going to cut and when the scissors were well secured 
in the place. Then, inside a bowl covered with parafilm, we cut the tip of the rostrum. To avoid contamination, we washed the scissors, bowl and the beak piece every time we cut a section. Subsections of the hood, i.e. IV to I, only comprising material from the hood, with subsection IV being the area just after the junction of the hood, crest and lateral wall in the rostrum. Beak parts were cleaned using $80 \%$ ethanol, stored in separated microtubes and dried in an oven at $60^{\circ} \mathrm{C}$. The different beak parts were reduced to a fine powder using a mixer mill Retsch® MM400 for 10 min with a frequency of $30 \mathrm{~s}^{-1}$.

UHL at each subsection (LS) was estimated following the equation (considering $3 \mathrm{~mm}$ for the tip of the rostrum):

$$
L S=\frac{U H L-3 m m}{4} \times S S_{n}
$$

where $\mathrm{SS}_{\mathrm{n}}$ is the subsection position in relation to the tip of the rostrum (Table 1).

Using the same samples, in which stable isotopic analyses were also conducted, total mercury (T-Hg - inorganic and organic forms hereafter mercury) was determined using an atomic absorption spectrometry (AAS) with thermal decomposition and gold amalgamation, using an Advanced Mercury Analyser (AMA) Leco® 254 [minimum detection of $0.01 \mathrm{ng}$ of mercury (Costley et al., 2000)]. This methodology requires, ideally, $\sim 35 \mathrm{mg}$ of sample but works with lower mass if the amount of mercury is above the minimum detection limit. It not requires a pre-treatment or digestion of the samples. During the analysis, replicates of certified reference materials (NIST® 2976 (mussel tissue) $-61.0 \pm 3.6 \mu \mathrm{g} \mathrm{kg}^{-1} \mathrm{dw}$ ) were analysed to secure the accuracy and precision of the method. The coefficient of variation was lower than $11 \%(n=12$; except measurements in ML_U10 where variation ranged between $7 \%$ and $51 \%$, likely due to very little mass) and a recovery efficiency of $87 \pm 4 \%$ ( $n=24)$. Because of the low mass of each subsection, $T$ $\mathrm{Hg}$ in $\mathrm{R}$ was determined on a single pooled sample (ML_U1+2+3+4+5+6+7+8+9+10 Table 1). For subsections IV, III, II and I samples were pooled in groups of three, except 
ML_U10 which was measured individually (ML_U1+2+3; ML_U4+5+6; ML_U7+8+9; ML_U10 - Table 1). These pools had beaks of similar size, ingested recently as toothfish stomachs do not retain cephalopod beaks for long periods (Pilling et al., 2001). Furthermore, as M. longimana have a short life-span of 1 to 3 years (Jarre et al., 1991; Laptikhovsky et al., 2013; Boyle and Rodhouse, 2005), these pools were constituted by individuals of similar size, age and maturation state. Individual stable isotopic analysis results showed little variation in $\delta^{13} \mathrm{C}$ and $\delta^{15} \mathrm{~N}$ values amongst the 10 individuals, suggesting similar habitat and trophic ecology. For these analyses, $\sim 0.35 \mathrm{mg}$ of each subsection (R, IV, III, II, I) were measured using a continuous flow isotope ratio mass spectrometry (Queirós et al., 2018). Thus, the result of the pool is expected to reflect the individuals' mercury levels.

Because $\mathrm{T}-\mathrm{Hg}$ concentration in $\mathrm{R}$ derive from just one value, this beak subsection was not considered in statistical analysis. To test differences in the $\mathrm{T}-\mathrm{Hg}$ concentrations between the four beak subsections, we performed a RM one-way ANOVA with Greenhouse-Geisser correction, proceeded by a Tukey's multiple comparison test to perform a pairwise comparison. The correlation between $\mathrm{T}-\mathrm{Hg}$ concentrations and LS and $\delta^{15} \mathrm{~N}$ was tested using a Pearson's correlation. As $\delta^{13} \mathrm{C}$ values (proxy for habitat) did not change significantly across subsections (Annex 1) they were not considered to analyse variations in the $\mathrm{T}-\mathrm{Hg}$ concentrations in this study. Statistical analyses were performed using Graphpad Prism ${ }^{\circledR}$ v6.01 using $\alpha=5 \%$. Images were prepared using Adobe Photoshop CC 2015® and Adobe Illustrator CC 2015®. 


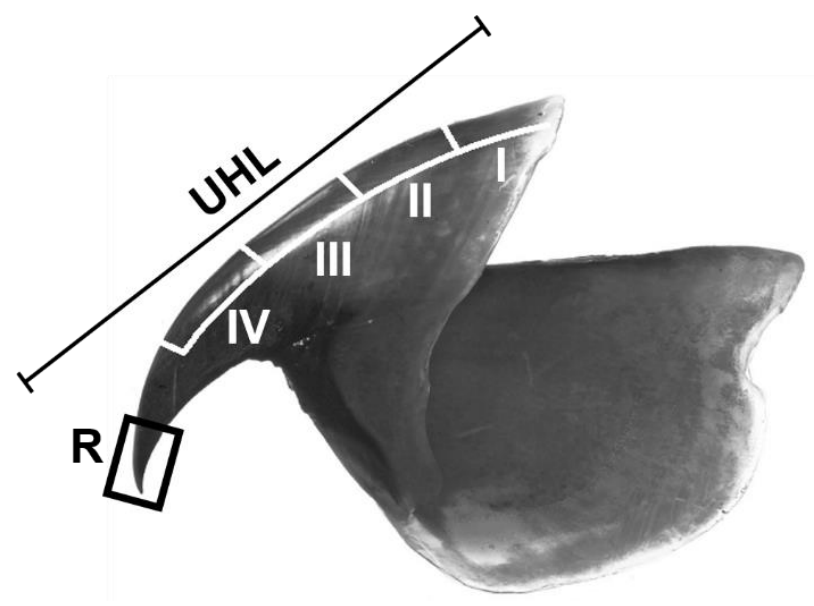

Fig. 1. Analysed beak sections. UHL: Upper Hood Length; R: Tip of the Rostrum; IV, III, II, I: analysed hood's subsections (IV is the first to be formed (juvenile) and I the last (adult). 


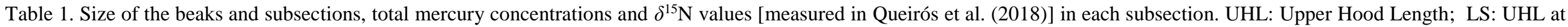
each subsection T-Hg: Total mercury concentrations; R: Tip of the Rostrum; IV, III, II, I: analysed hood's subsections (IV is the first to be formed (juvenile) and I the last (adult).

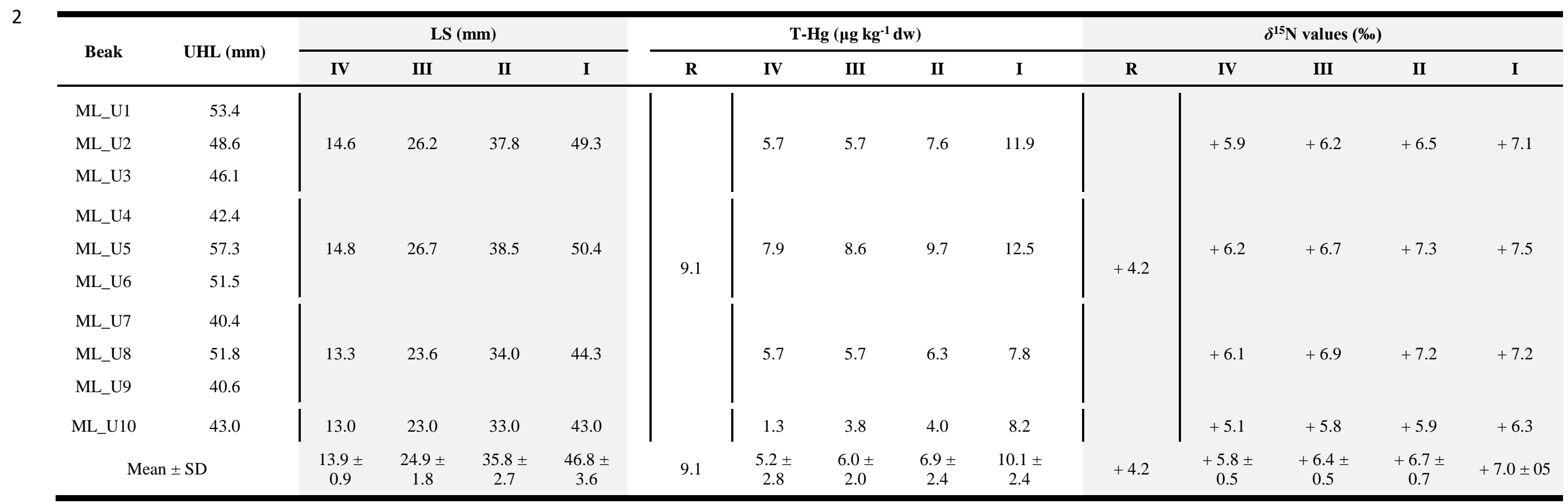




\section{Results}

The values of T-Hg ranged from 0.8 to $12.6 \mu \mathrm{g} \mathrm{kg}^{-1} \mathrm{dw}$ in ML_U10 subsection IV and ML_U4+5+6 subsection I, respectively (Table 1). Generally, the T-Hg increased from subsection IV to subsection I: the lowest $\mathrm{T}-\mathrm{Hg}$ were found in the subsection IV $\left(\right.$ Mean \pm SD: $\left.5.1 \pm 2.6 \mu \mathrm{g} \mathrm{kg}^{-1} \mathrm{dw}\right)$ and the highest in subsection I (Mean \pm SD: $10.1 \pm$ $2.6 \mu \mathrm{g} \mathrm{kg}^{-1} \mathrm{dw}$ ) (Table 1, Fig. 2). The T-Hg of R was higher than those from subsections III and IV (Table 1). Significant differences were found between the four subsections (RM one-way ANOVA with Greenhouse-Geisser correction, $F_{1.445,10.11}=27.93, p<0.001$ ) with Tukey's multiple comparison test showing specific differences between subsections (Fig. 2). Significant positive correlations were found between LS and T-Hg (Pearson's correlation, $\mathrm{n}=16, \mathrm{r}=0.724, p=0.002)$. T-Hg also correlated positively with $\delta^{15} \mathrm{~N}$ values (Pearson's correlation, $\mathrm{n}=16, \mathrm{r}=0.799, p<0.001$ ) (Fig. 3).

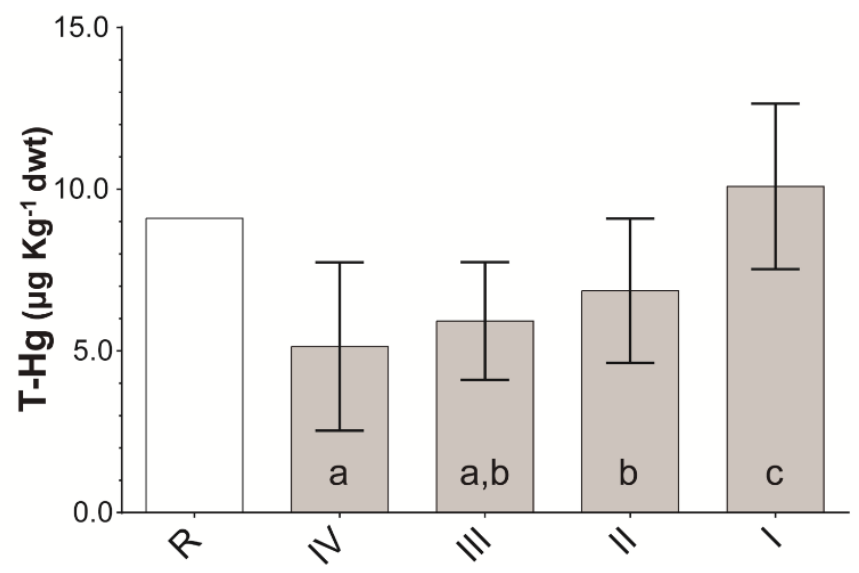

Fig. 2. Total mercury concentrations in the different beak sections. Bars with different letters are significantly different (Tukey's multiple comparison test). White bar = tip of the rostrum, $\mathrm{n}=1$ with 1 replicate (not included in statistical analysis and without SD); Grey bar = subsections of the hood values, $\mathrm{n}=4$ with 2 replicates each ( 8 values per bar). Values are mean \pm SD. 


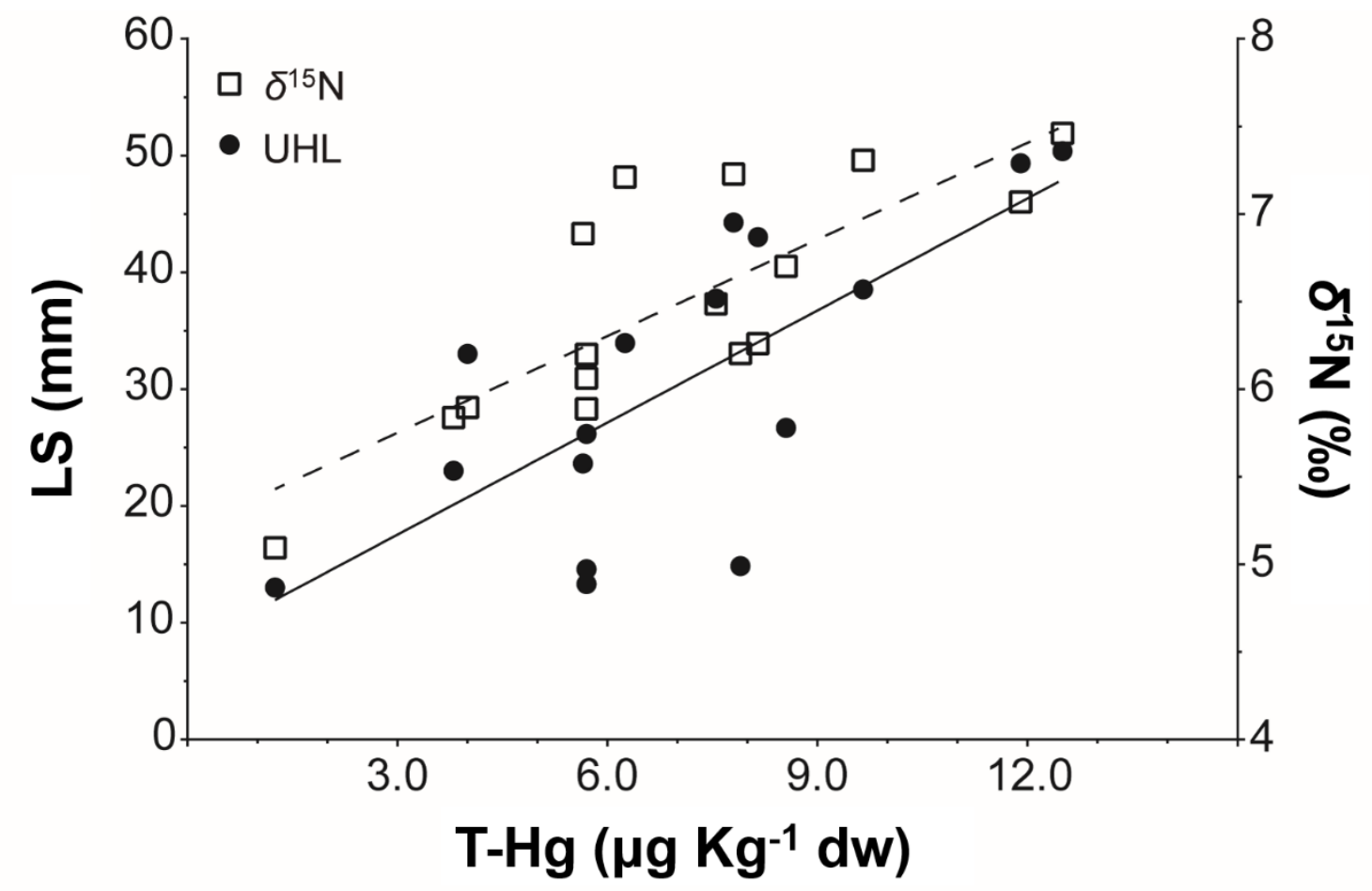

Fig. 3. Correlations between total mercury concentrations and LS and $\delta^{15} \mathrm{~N}$ values from subsections IV to I (Queirós et al., 2018). LS: UHL at each subsection; T-Hg: Total mercury; Straight line: correlation between T-Hg and UHL ( $\mathrm{r}=0.7243, p=0.002)$; Dashed line: correlation between $\mathrm{T}-\mathrm{Hg}$ and $\delta^{15} \mathrm{~N}$ values $(\mathrm{r}=0.7989, p<0.001)$. Each point represents the average of LS and $\delta^{15} \mathrm{~N}$ value for each subsection pool.

\section{Discussion}

\subsection{Mercury analysis along cephalopod beaks as a reliable method}

Cephalopod beaks grow throughout the life of the individuals without replacement. The rostrum is the first region to be formed with the lateral wall, crest and hood growing continuously by the addition of new beak material (Perales-Raya et al., 2010, 2014a, 2014b, 2018; Queirós et al, 2018). Mercury bioaccumulates in organisms, increasing from early life-stages to adults (Jakimska et al., 2011). The lowest mercury levels found in subsection IV (formed earlier in squid ontogeny) and the highest concentrations in subsection I (last to be formed) show that different upper beaks' sections can be used to evaluate how mercury concentrations change throughout an individuals' 
life: the anterior region of the hood (subsection IV) reflecting the earlier life stages and the posterior part of the hood (subsection I) reflecting the adult stage.

Unexpectedly, the tip of the rostrum ( $\mathrm{R}$ - first beak region to be formed in squid's life) presented the highest concentration of mercury. This is possibly explained by the continuous formation of daily beak material throughout the life of the individual in this area as shown in previous (Perales-Raya et al., 2010, 2014b). Such daily increment can suggest that $\mathrm{R}$ can deliver an average value of mercury exposure of the entire squids' life. However, R also contains more proteins than the rest of the beak (Miserez et al., 2008), favouring mercury binding in comparison to the rest of the beak. This affinity between mercury and proteins in cephalopods was already showed (Bustamante et al., 2006). Nevertheless, and because this result derives from one pooled analysis of 10 beaks, future studies should analyse this region in more detail. Future studies can also explore the hypothesis of, using a more detailed technique (e.g. LA-ICP-MS), relate mercury concentrations with a specific age in days.

Mercury concentrations in this study ( 0.8 to $\left.12.6 \mu \mathrm{g} \mathrm{kg}^{-1} \mathrm{dw}\right)$, as in whole beaks [4.0 to $13.0 \mu \mathrm{g} \mathrm{kg}^{-1} \mathrm{dw}$ in M. longimana; and 4.0 to $70.0 \mu \mathrm{g} \mathrm{kg}^{-1} \mathrm{dw}$ in other species such as Adeliedone polymorpha, Filippovia knipovitchi, Galiteuthis glacialis, Gonatus antarcticus Pareledone turqueti and,Psychroteuthis glacialis (Matias et al., 2019; Xavier et al., 2016a)], are 10 times lower than in other tissues of Southern Ocean cephalopods (80 to $110 \mu \mathrm{g} \mathrm{kg}^{-1} \mathrm{dw}$ in muscle tissue of M. longimana; and to a maximum of $310 \mu \mathrm{g} \mathrm{kg}^{-}$ ${ }^{1} \mathrm{dw}$ in other Southern Ocean squid; and to $600 \mu \mathrm{g} \mathrm{kg}^{-1} \mathrm{dw}$ in benthic Antarctic octopods (Anderson et al., 2009; Matias et al., 2019; McArthur et al., 2003; Xavier et al., 2016a). Similar differences are also found in different world regions (up to 1998 and $3320 \mu \mathrm{g} \mathrm{kg}^{-}$ ${ }^{1} \mathrm{dw}$ in Todarodes sagittatus and Architeuthis dux, respectively (Bustamante et al., 2006, 2008; Chouvelon et al., 2012; Pierce et al., 2008). This difference suggests that beaks 
accumulate far less mercury than soft tissues, showing an important inter-tissue variability in mercury concentrations in cephalopods (Bustamante et al., 2008). Despite analysing muscle and beaks, Xavier et al. (2016a) analysed tissues from different individuals precluding a direct comparison in the accumulation rates of different tissues. Following the work of Cherel et al. (2009) with stable isotopes, we suggest that future studies should analyse mercury concentrations in different tissues from the same individuals to evaluate the inter-tissue variability. Although we tested this methodology in large beaks, it has potential to be applied to a variety of beak sizes of different species. It might be necessary to pool different beaks of similar size, particular from cephalopod species with small beaks, to obtain a minimum mass to secure a confident result. We suggest that this technique can be used to assess other important trace elements throughout cephalopods' life, as recent studies using Moroteuthopsis ingens lower beaks showed that beaks can also accumulate other trace elements (Northern et al., 2019; Rodríguez-Navarro et al., 2006). Despite we used upper beaks, this technique can also be applied to the lower beak. With results obtained from these analyses (e.g. mercury, other trace elements, stable isotope analysis) and relate it to age information, it can possible determine the bioaccumulation in relation to the specific age in days (discussed above).

\subsection{Mercury levels through the life-cycle of $M$. longimana in relation to its ecology}

Mercury concentrations in the different beak sections show that adults (subsection I) exhibit twice as much mercury as juveniles (subsection IV). Thus, predators feeding on adults [e.g. wandering albatrosses (Xavier et al., 2003)] should receive twice as much more mercury from $M$. longimana than those feeding on juveniles [e.g. king penguins (Cherel and Weimerskirch, 1999)]. As cephalopods bioaccumulate mainly methylated mercury (Bustamante et al., 2006), the feeding of the different $M$. longimana life stages 
may influence the exposure of predators to mercury and consequently $\mathrm{Hg}$ levels in their tissues. Nevertheless, predators' mercury exposure can be influenced by the habitat of $M$. longimana, as previous studies showed that mercury values in the organisms may vary with the location (Seco et al., 2019).

To our knowledge, only one study analysed mercury levels in the beaks of $M$. longimana, obtaining lower concentrations than our study (Xavier et al., 2016a). This difference can be explained by the methodological approach because Xavier et al., (2016a) analysed the whole beak, measuring an average value of the entire squid's life. Also, Xavier et al., (2016a) analysed smaller individuals that are expected to have lower mercury levels. Though we cannot compare directly the mantle length because no allometric equations are available for upper beaks, the size and coloration of beaks (Clarke, 1986; Xavier and Cherel, 2009) in both studies strongly suggest the difference in the size of the studied individuals. Furthermore, this difference can also be related with the sex of the studied individuals as it is suggested that sex can have an influence on mercury concentrations, in particular in sexually dimorphic species, e.g. Loligo forbesi (Monteiro et al., 1992), as the case of M. longimana (Laptikhovsky and Xavier, 2017). Nevertheless, because both studies analysed beaks from unsexed specimens and Xavier et al. (2016a) only analysed 6 beaks, we suggest that a future studies should analyse this sex-related differences in mercury concentrations of M. longimana.

The correlation between SL and mercury levels (excluding the tip of the rostrum) suggests a continuous bioaccumulation throughout an individuals' life-cycle. Indeed, differences between non-adjacent subsections suggest a continuous increase in mercury accumulation throughout the squid's life-cycle. Different results (no correlation between beak size and mercury concentrations), were obtained in entire lower beaks of $M$. longimana from the same study region (Xavier et al., 2016a). Differences might result 
from the use of entire lower beaks in Xavier et al., (2016a) which delivers an average value for the entire individuals' life cycle (discussed above). The difference of subsection I suggests a higher mercury accumulation rate in the end of the life-cycle of M. longimana compared to the beginning and middle of its life-cycle. Changes in accumulation rates during its life may relate with a dietary shift during its life cycle. Previous studies, using different techniques, suggest a change from zooplankton in early life to higher trophic levels (e.g. fish and squid) as adults (Cherel and Hobson, 2005; Nemoto et al., 1985, 1988; Seco et al., 2016). Indeed, stable isotopes of $\delta^{15} \mathrm{~N}$ in the same sections used in this study suggest an increase of one trophic level from section R to section IV, supporting a dietary shift between the formation of both beak sections (Queirós et al., 2018). Mercury trophic biomagnification (Chouvelon et al., 2012; Jarman et al., 1996) would explain the increase of mercury from subsection IV to subsection III, as the main diet shift happens early in the squid life (Queirós et al., 2018). However, such shift is not reflected in a high increase in mercury levels. But, it is in this period of its life-cycle (i.e. from subsection IV to subsection III) that $M$. longimana present high growing rates (Bizikov, 1991), suggesting a dilution effect during this period.

Similar $\delta^{15} \mathrm{~N}$ values between subsection II and I suggest that $M$. longimana feed at the same trophic position and prey during the second-half of squid's life cycle (Queirós et al., 2018). Therefore, the rapid increase of mercury between these subsections possibly relates with an increasing feeding rate as squid prepares to reproduce.

Mercury concentrations generally increase with size in squid [for review, see Penicaud et al. (2017) but also Lischka et al. (2018, 2019)]. However, some studies did not find this relationship to be significant for some oceanic, such as M. ingens (McArthur et al., 2003), Illex coindetii and Todarodes sagittatus (Bustamante et al., 2006), nor for some neritic squid such as Loligo forbesi (Bustamante et al., 2006) and Loligo sp. (Ahmad 
et al., 2015). Furthermore, Xavier et al. (2016a) found a negative relation between mercury concentrations and the estimated mantle size of five Southern Ocean squid species (all species together). Such interspecific difference might relate the species' ontogeny, the prey type or even environmental conditions (Penicaud et al., 2017).

Values of $\delta^{15} \mathrm{~N}$ are commonly used to determine the trophic position of animals in marine systems, including Southern Ocean cephalopods (Cherel and Hobson, 2005). Positive correlations found between mercury levels and $\delta^{15} \mathrm{~N}$ values [analysed in Queirós et al. (2018)] of each subsection confirm that trophic biomagnification influences mercury levels in M. longimana (Chouvelon et al., 2012; Jarman et al., 1996). Similar results were obtained for other cephalopod species in the Southern Ocean and Northeast Atlantic (Chouvelon et al., 2012). Lower mercury levels of $M$. longimana in comparison with smaller Southern Ocean squid species, e.g. Alluroteuthis antarcticus, F. knipovitchi, G. glacialis, G. antarcticus, M. ingens and P. glacialis (McArthur et al., 2003; Seco et al., 2020; Xavier et al., 2016a), might relate with differences in the trophic position. Indeed, these species present higher $\delta^{15} \mathrm{~N}$ values than M. longimana, thus higher trophic position (Alvito et al., 2015; Anderson et al., 2009; Queirós et al., 2018; Seco et al., 2016). Recent analyses using compound-specific isotopic analysis of amino acids on beaks (which overcomes the depletion of chitin in ${ }^{15} \mathrm{~N}$ and improve the knowledge on the food web functioning) of M. longimana confirmed that this squid feeds at low trophic level (Cherel et al., 2019).

\section{Conclusions}

Here we evaluated the $\mathrm{T}-\mathrm{Hg}$ concentrations in different subsections of $M$. longimana's upper beaks to demonstrate it as a reliable technique to investigate the variation of mercury exposure throughout a cephalopod life-cycle. Moreover, we 
confirmed that $M$. longimana bioaccumulate mercury throughout its life, with adults being exposed two times more than juveniles, which might affect the top predators exposure to mercury according to the different life-stages of this squid. With a clear relationship between mercury concentrations and $\delta^{15} \mathrm{~N}$ values [obtained in Queirós et al. (2018)], we confirmed that trophic magnification of mercury influences the mercury concentrations in this species.

Future studies should analyse the anterior section of the hood (adjacent to the tip of the rostrum) and the posterior section of the hood to evaluate mercury levels in individual's juvenile and adult life-stage, respectively. Our results do not show that the tip of the rostrum is a reliable section to study mercury concentrations in any specific period of cephalopods' life-cycle. Because we just obtained one value for this region due to the low sample mass available, specific studies should be devoted to the rostrum in particular in the future. Despite we tested the technique using large M. longimana upper beaks, this technique can also be applied to species with smaller beaks, however with the possibility to pool different beaks, and to lower beaks as for stable isotopes (Queirós et al., 2018). Furthermore, future studies can also apply this technique in beak regions where it is possible to determine the age of the individual, e.g. Rostrum Sagittal Section (PeralesRaya et al., 2014b) and study the bioaccumulation in different squid species and related with the age, or analyse different trace elements.

\section{Acknowledgements}

This work is part of SCAR AnT-ERA, ICED, CEPH-BAS and SCAR-EGBAMM programs and this study benefitted from the strategic programme of MARE, financed by FCT (MARE - UID/MAR/04292/2013). JQ was supported by a travel grant by SCAR under the program SCAR AnT-ERA. The IUF (Institut Universitaire de France) is also 
acknowledged for its support to PB as a Senior Member. We acknowledge the Portuguese Foundation for the Science and Technology (FCT) through a $\mathrm{PhD}$ grant to JS (SRFH/PD/BD/113487). JPC is funded by CESAM (UID/AMB/50017/2019) and the Integrated Program of SR\&TD 'Smart Valorization of Endogenous Marine Biological Resources Under a Changing Climate' (Centro-01-0145-FEDER-000018), co-funded by Centro 2020 program, Portugal 2020 and the European Regional Development Fund. The authors would like to thanks to the three anonymous reviewers that helped to improve the quality of the manuscript.

\section{References}

Ahmad, N.I., Noh, M.F.M., Mahiyuddin, W.R.W., Jaafar, H., Ishak, I., Azmi, W.N.F.W., Veloo, Y., Mokhtar, F.A., 2015. The mercury levels in crustaceans and cephalopods from Peninsular Malaysia. Environ. Sci. Pollut. Res. 22, 1296012974. https://doi.org/10.1007/s11356-015-4415-9.

Alvito, P.M., Rosa, R., Phillips, R.A., Cherel, Y., Ceia, F., Guerreiro, M., Seco, J., Baeta, A., Vieira, R.P., Xavier, J.C., 2015. Cephalopods in the diet of nonbreeding blackbrowed and grey-headed albatrosses from South Georgia. Polar Biol. 38, 631-641. https://doi.org/10.1007/s00300-014.1626-3.

Anderson, O.R.J., Phillips, R.A., McDonald, R.A., Shore, R.F., McGill, R.A.R., Bearhop, S., 2009. Influence of trophic position and foraging range on mercury levels within a seabird community. Mar. Ecol. Prog. Ser. 375, 277-288. https://doi.org/10.3354/meps07784.

Bizikov, V.A., 1991. A new method of squid age determination using otoliths N.T.R. I.T.P.P. Special Publication, 39-51.

Bolstad, K.S.R., Braid, H.E., Strugnell, J.M., Lindgren, A.R., Lischka, A., Kubodera, T., Laptikhovsky, V.L., Labiaga, A.R., 2018. A mitochondrial phylogeny of the 
family Onychoteuthidae Gray, 1847 (Cephalopoda: Oegopsida). Mol. Phylogen.

Evol. 128, 88-97. https://doi.org/10.1016/j.ympev.2018.05.032.

Boyle, P., Rodhouse, P., 2005. Cephalopods: Ecology and Fisheries. Blackwell Science Lda, Oxford.

Bustamante, P., Gonzalez, A.F., Rocha, F., Miramand, P., Guerra, A., 2008. Metal and metalloid concentrations in the giant squid Architeuthis dux from Iberian waters. $\begin{array}{llll}\text { Mar. } & \text { Environ. } & \text { Res. }\end{array}$ https://doi.org/10.1016/j.marenvres.2008.04.003.

Bustamante, P., Lahaye, V., Durnez, C., Churlaud, C., Caurant, F., 2006. Total and organic $\mathrm{Hg}$ concentrations in cephalopods from the North Eastern Atlantic waters: influence of geographical origin and feeding ecology. Sci. Total Environ. 368, 585-596. https://doi.org/10.1016/j.scitotenv.2006.01.038.

Carravieri, A., Cherel, Y., Jaeger, A., Churlaud, C., Bustamante, P., 2016. Penguins as bioindicators of mercury contamination in the southern Indian Ocean: geographical and temporal trends. Environ. Pollut. 213, 195-205. https://doi.org/10.1016/j.envpol.2016.02.010.

Cherel, Y., Barbraud, C., Lahournat, M., Jaeger, A., Jaquemet, S., Wanless, R.M., Phillips, R.A., Thompson, D.R., Bustamante, P., 2018. Accumulate or eliminate? Seasonal mercury dynamics in albatrosses, the most contaminated family of birds. Environ. Pollut. 241, 124-135. https://doi.org/10.1016/j.envpol.2018.05.048.

Cherel, Y., Bustamante, P., Richard, P., 2019. Amino acid $\delta^{13} \mathrm{C}$ and $\delta^{15} \mathrm{~N}$ from scletorized beaks: a new tool to investigate the foraging ecology of cephalopods, including giant and colossal squids. Mar. Ecol. Progr. Ser. 624, 89-102. https://doi.org/10.3354/meps13002. 
Cherel, Y., Fontaine, C., Jackson, G.D., Jackson, C.H., Richard, P., 2009. Tissue, ontogenic and sex-related differences in $\delta^{13} \mathrm{C}$ and $\delta^{15} \mathrm{~N}$ values of the oceanic squid Todarodes filippovae (Cephalopoda: Ommastrephidae). Mar. Biol. 156, 699-708. https://doi.org/10.1007/s00227-008-1121-x.

Cherel, Y., Hobson, K.A., 2005. Stable isotopes, beaks and predators: a new tool to study the trophic ecology of cephalopods, including giant and colossal squids. Proc. R. Soc. Lond. B. Biol. Sci. 272, 1601-1607. https://doi.org/10.1098/rspb.2005.3115.

Cherel, Y., Weimerskirch, H., 1999. Spawning cycle of onychoteuthidae squids in the southern Indian Ocean: new information from seabird predators. Mar. Ecol. Prog. Ser. $188,93-104$.

Chouvelon, T., Spitz, J., Caurant, F., Mèndez-Fernandez, P., Autier, J., Lassus-Débat, A., Chappuis, A., Bustamante, P., 2012. Enhanced bioaccumulation of mercury in deep-sea fauna from the Bay of Biscay (north-east Atlantic) in relation to trophic positions identified by analysis of carbon and nitrogen stable isotopes. Deep Sea Res. I: Oceanogr. Res. Pap. 65, 113-124. https://doi.org/10.1016/j.dsr.2012.02.010.

Chouvelon, T., Spitz, J., Cherel, Y., Caurant, F., Sirmel, R., Mèndez-Fernandez, P., Bustamante, P., 2011. Inter-specific and ontogenic differences in $\delta^{13} \mathrm{C}$ and $\delta^{15} \mathrm{~N}$ values and $\mathrm{Hg}$ and $\mathrm{Cd}$ concentrations in cephalopods. Mar. Ecol. Prog. Ser. 433, 107-120. https://doi.org/10.3354/meps09159.

Clarke, M.R., 1986. A handbook for the identification of cephalopod beaks, Marine Biological Association of the United Kindgom ed. Clarendon Press, Oxford.

Cossa, D., Heimbürger, L.E., Lannuzel, D., Rintoul, S.R., Butler, E.C.V., Bowie, A.R., Averty, B., Watson, R.J., Remenyi, T., 2011. Mercury in the Southern Ocean. 
Geochim. Cosmochim. Acta 75, 4037-4052. https://doi.org/10.1016/j.gca.2011.05.001.

Costley, C.T., Mossop, K.F., Dean, J.R., Garden, L.M., Marshall, J., Carroll, J., 2000. Determination of mercury in environmental and biological samples using pyrolysis atomic absorption spectrometry with gold amalgamation. Anal. Chim. Acta 405, 179-183. https://doi.org/10.1016/S0003-2670(99)00742-4

Eagles-Smith, C.A., Silbergeld, E.K., Basu, N., Bustamante, P., Diaz-Barriga, F., Hopkins, W.A., Kidd, K.A., Nyland, J.F., 2018. Modulators to mercury risk to wildlife and humans in the context of rapid global change. Ambio. 47, 170-197. https://doi.org/10.1007/s13280-017-1011-x.

Griffiths, H.J., 2010. Antarctic Marine Biodiversity - What do we know about the distribution of life in the Southern Ocean? PLoS One 5, e11683. https://doi.org/10.1371/journal.pone.0011683.

Guerra, A., Rodríguez-Navarro, A.B., González, A.F., Romanek, C.S., Álvarez-Lloret, P., Pierce, G.J., 2010. Life-history traits of the giant squid Architeuthis dux revealed from stable isotope signatures recorded in beaks. ICES J. Mar. Sci. 67, 1425-1431. https://doi.org/10.1093/icesjms/fsq091.

Jakimska, A., Konieczka, P., Skóra, K., Namiesnik, J., 2011. Bioaccumulation of metals in tissues of marine animals, part I: the role and impact of heavy metals on organisms. Pol. J. Environ. Stud. 20, 1117-1125.

Jarman, W.M., Hobson, K.A., Sydeman, W.J., Bacon, C.E., McLaren, E.B., 1996. Influence of trophic position and feeding location on contaminant levels in the Gulf of the Farallones food web revealed by stable isotope analysis. Environ. Sci. Technol. 30, 654-660. https://doi.org/10.1021/es950392n 
Jarre, A., Clarke, M.R., Pauly, D., 1991. Re-examination of growth estimates in oceanic squids: the case of Kondakovia longimana (Onychoteuthidae). ICES J. Mar. Sci. $48,195-200$

Karagas, M.R., Choi, A.L., Oken, E., Horvat, M., Schoeny, R., Kamai, E., Cowell, W., Grandjean, P., Korrick, S., 2012. Evidence on the human health effects of lowlevel methylmercury exposure. Environ. Health Perspect. 120, 799-806. https://doi.org/10.1289/ehp.1104494.

Laptikhovsky, V., Collins, M.A., Arkhipkin, A., 2013. First case of possible iteroparity among coleoid cephalopods: the Giant Warty Squid Kondakovia longimana. J. Mol. Studies, 79: 270-272, https://doi.org/10.1093/mollus/eyt014

Laptikhovsky, V., Xavier, J.C., 2017. Dwarf males of giant warty squid Kondakovia longimana and a description of their spermatophores. Polar Biol. 40, 2469-2474. https://doi.org/10.1007/s00300-017-2158-4.

Lischka, A., Lacoue-Labarthe, T., Hoving, H.J.T., JavidPour, J., Pannell, J.L., Merten, V., Churlaud, C., Bustamante, P., 2018. High cadmium and mercury concentrations in the tissues of the orange-back flying squid, Sthenoteuthis pteropus, from the tropical Eastern Atlantic. Ecotoxicol. Environ. Saf. 163, 323330. https://doi.org/10.1016/j.ecoenv.2018.07.087.

Lischka, A., Lacoue-Labarthe, T., Bustamante, P., Piatkowski, U., Hoving, H.J., 2020. Trace element analysis reveals bioaccumulation in the squid Gonatus fabricii from polar regions of the Atlantic Ocean. Environ. Pollut. 256, 113389. https://doi.org/10.1016/j.envpol.2019.113389.

Lourenço, H.M., Anacleto, P., Afonso, C., Ferraria, V., Martins, M.F., Carvalho, M.L., Lino, A.R., Nunes, M.L., 2009. Elemental composition of cephalopods from 
Portuguese continental waters. Food Chem. 113, 1146-1153. https://doi.org/10.1016/j.foodchem.2008.09.003.

Lynnes, A.S., Rodhouse, P.G., 2002. A big mouthful for predators: the largest recorded specimen of Kondakovia longimana (Cephalopoda: Onychoteuthidae). Bull. Mar. Sci. 71, 1087-1090. https://doi.org/10.1080/03036758.1992.10420819.

Mason, R.P., Choi, A.L., Fitzgerald, W.F., Hammerschmidt, C.R., Lamborg, C.H., Soerensen, A.L., Sunderland, E.M., 2012. Mercury biogeochemical cycling in the ocean and policy implications. Environ. Res. 119, 101-117. https://doi.org/10.1016/j.envres.2012.03.013

Matias, R.S., Gregory, S., Ceia, F.R., Baeta, A., Seco, J., Rocha, M.S., Fernandes, E.M., Reis, R.L., Silva, T.H., Pereira, E., Piatkowski, U., Ramos, J.A., Xavier, J.C., 2019. Show your beaks and we tell you what you eat: Different ecology in sympatric Antarctic benthic octopods under a climate change context. Mar. Environ. Res. 150, 104757. https://doi.org/10.1016/j.marenvres.2019.104757.

McArthur, T., Butler, E.C.V., Jackson, G.D., 2003. Mercury in the marine food chain in the Southern Ocean at Macquarie Island: an analysis of a top predator, Patagonian toothfish (Dissostichus eleginoides) and a mid-trophic species, the warty squid (Moroteuthis ingens). Polar Biol. 27, 1-5. https://doi.org/10.1007/s00300-0030560-6.

Miserez, A., Rubin, D., Waite, J.H., 2010. Cross-linking chemistry of squid beak. J. Biol. Chem. 285, 38115-38124. https://doi.org/10.1074/jbc.M110.161174.

Miserez, A., Schneberk, T., Sun, C., Zok, F.W., Waite, J.H., 2008. The transition from stiff to compliant materials in squid beaks. Science $319,1816-1819$. https://doi.org/10.1126/science.1154117. 
Monteiro, L.R., Porteiro, F.M., Gonçalves, J.M., 1992. Inter- and intra-specific variation of mercury levels in muscle of cephalopods from the Azores. Arquipelago 10, 1322.

Nemoto, T., Okiyama, M., Iwasaki, N., Kikuchi, T., 1988. Squid as predators on krill (Euphausia superba) and prey for sperm whales in the Southern Ocean, in: Sahrhage, D. (Ed.), Antarctic Ocean and resources variability. Springer-Verlag, Berlin Heidelberg, pp. 292-296. https://doi.org/10.1007/978-3-642-73724-4_25.

Nemoto, T., Okiyama, M., Takahashi, M., 1985. Aspects of the roles of squid in food chains of marine Antarctic ecosystems, in: Siegfried, W.R., Condy, P.R., Laws, R.M. (Eds.), Antarctic Nutrient Cycles and Food Webs. Springer-Verlag, Berlin Heidelberg, pp. 415-420. https://doi.org/10.1007/978-3-642-82275-9_58.

Northern, T.J., Smith, A.M., McKinnon, J.F., Bolstad, K.S.R., 2019. Trace elements in beaks of greater hooked squid Onykia ingens: opportunities for environmental $\begin{array}{llll}\text { tracing. } & \text { Molluscan } & \text { 29-34. }\end{array}$ https://doi.org/10.1080/13235818.2018.1495604.

Penicaud, V., Lacoue-Labarthe, T., Bustamante, P., 2017. Metal bioaccumulation and detoxification processes in cephalopods: A review. Environ. Res. 155, 123-133. https://doi.org/10.101/j.envres.2017.02.003.

Perales-Raya, C., Bartolomé, A., García-Santamaria, M.T., Pascual-Alayón, P., Almansa, E., 2010. Age estimation obtained from analysis of octopus (Octopus vulgaris Cuvier, 1797) beaks: Improvements and comparisons. Fish. Res. 106, 171-176, https://doi.org/10.1016/j.fishres.2010.05.003.

Perales-Raya, C., Almansa, E., Bartolomé, A., Felipe, B.C., Iglesias, J., Sánchez, F.J., Carrasco, J.F., Rodríguez, C., 2014a. Age validation in Octopus vulgaris beaks 
accross the full ontogenetic range: beaks as recorders of life events in octopuses. J. Shell. Res. 33, 481-493, https://doi.org/10.2983/035.033.0217

Perales-Raya, C., Jurado-Ruzafa, A., Bartolomé, A., Duque, V., Carrasco, M.N., FraileNuez, E., 2014b. Age of spent Octopus vulgaris and stress mark analysis using beaks of wild individuals. Hydrobiologia 725, 105-114. https://doi.org/10.1007/s10750-013-1602-x.

Perales-Raya, C., Nande, M., Roura, A., Bartolomé, A., Gestal, C., Otero, J.J., GarcíaFernández, P., Almansa, E., 2018. Comparative study of age estimation in wild and cultured Octopus vulgaris paralarvae: effect of temperature and diet. Mar. Ecol. Progr. Ser. 598, 247-259, https://doi.org//10.3354/meps12218.

Pierce, G.J., Stowasser, G., Hastie, L.C., Bustamante, P., 2008. Geographic, seasonal and ontogenetic variation in cadmium and mercury concentrations in squid (Cephalopoda: Teuthoidea) from UK waters. Ecotoxicol. Environ. Saf. 70, 422432. https://doi.org/10.1016/j.ecoenv.2007/07/007.

Pilling, G.M., Purves, M.G., Daw, T.M., Agnew, D.A., Xavier, J.C., 2001. The stomach contents of Patagonian toothfish around South Georgia (South Atlantic). J. Fish Biol. 59, 1370-1384. https://doi.org/10.1111/j.1095-8649.2001.tb00198.x.

Queirós, J.P., Cherel, Y., Ceia, F.R., Hilário, A., Roberts, J., Xavier, J.C., 2018. Ontogenic changes in habitat and trophic ecology in the Antarctic squid Kondakovia longimana derived from isotopic analysis on beaks. Polar Biol. 41, 2409-2421. https://doi.org/10.1007/s00300-018-2376-4.

Roberts, J., Xavier, J.C., Agnew, D.J., 2011. The diet of toothfish species Dissostichus eleginoides and Dissostichus mawsoni with overlapping distributions. J. Fish Biol. 79, 138-154. https://doi.org/10.1111/j.1095-8649.2011.03005.x. 
Rodhouse, P.G.K., Griffiths, H.J., Xavier, J.C., 2014. Southern Ocean Squid, in: De Broyer, C., Koubbi, P., Griffiths, H., Raymond, B., d'Acoz, C.U., Van de Putte, A., Danis, B., David, B., Grant, S., Gutt, J., Held, C., Hosie, G., Huettmann, F., Post, A., Ropert-Coudert, Y. (Eds.), The biogeographic atlas of the Southern Ocean. The Scientific Committee on Antarctic Research, Cambridge, UK, pp. 284-289.

Rodríguez-Navarro, A., Guerra, A., Romanek, C.S., Rocha, F., González, A.F., 2006. Life history of the giant squid Architeuthis as revealed from stable isotope and trace elements signatures recorded in its beaks, in: Cephalopod Life Cycles, Cephalopod International Advisory Council Symposium 2006, Hobart, Tasmania, pp. 79.

Ruiz-Cooley, R.I., Markaida, U., Gendron, D., Aguíñiga, S., 2006. Stable isotopes in jumbo squid (Dosidicus gigas) beaks to estimate its trophic position: comparison between stomach contents and stable isotopes. J. Mar. Biol. Ass. U. K. 86, 437445 ,

Seco, J., Roberts, J., Ceia, F.R., Baeta, A., Ramos, J.A., Paiva, V.H., Xavier, J.C., 2016. Distribution, habitat and trophic ecology of Antarctic squid Kondakovia longimana and Moroteuthis knipovitchi: inferences from predators and stable isotopes. Polar Biol. 39, 167-175. https://doi.org/10.1007/s00300-015-1675-2.

Seco, J., Xavier, J.C., Brierley, A.S., Bustamante, P., Coelho, J.P., Gregory, S., Fielding, S., Pardal, M.A., Pereira, B., Stowasser, G., Tarling, G.A., Pereira, E., 2020. Mercury levels in Southern Ocean squid: Variability over the last decade. Chemosphere 239, 124785. https://doi.org/10.1016/j.chemosphere.2019.124785.

Seco, J., Xavier, J.C., Coelho, J.P., Pereira, B., Tarling, G., Pardal, M.A., Bustamante, P., Stowasser, G., Brierley, A.S., Pereira, M.E., 2019. Spatial variability in total and 
organic mercury levels in Antarctic krill Euphausia superba across the Scotia Sea. Environ. Pollut. 247, 332-339. https://doi.org/10.1016/j.envpol.2019.01.031.

Stern, G.A., Macdonald, R.W., Outridge, P.M., Wilson, S., Chételat, J., Cole, A., Hintelmann, H., Loseto, L.L., Steffen, A., Wang, F., Zdanowicz, C., 2012. How does climate change influence Arctic mercury? Sci. Total Environ. 414, 22-42. https://doi.org/10.1016/j.scitotenv.2011.10.039.

Streets, D.G., Devane, M.K., Lu, Z., Bond, T.C., Sunderland, E.M., Jacob, D.J., 2011. All-time releases of mercury to the atmosphere from human activities. Environ. Sci. Technol. 45, 10485-10491. https://doi.org/10.1021/acs.est.7b00451.

Tan, Y., Hoon, S., Guerette, P.A., Wei, W., Ghadban, A., Hao, C., Miserez, A., Waite, J.H., 2015. Infiltration of chitin by protein coacervates defines the squid beak mechanical gradient. Nat. Chem. Biol. 11, 488-495. https://doi.org/10.1038/nchembio.1833.

Tavares, S., Xavier, J.C., Phillips, R.A., Pereira, M.E., Pardal, M.A., 2013. Influence of age, sex and breeding status on mercury accumulation patterns in the wandering albatross Diomedea exulans. Environ. Pollut. 181, 315-320. https://doi.org/10.1016/j.envpol.2013.06.032.

Wolfe, M.E., Schwarzbach, S., Sulaiman, R.A., 1998. Effects of mercury on wildlife: a comprehensive review. Environ. Toxicol. Chem. 17, 146-160. https://doi.org/10.1002/etc.5620170203.

Xavier, J., Croxall, J., Trathan, P., Rodhouse, P., 2003. Inter-annual variation in the cephalopod component of the diet of the wandering albatross, Diomedea exulans, breeding at Bird Island, South Georgia. Mar. Biol. 142, 611-622. https://doi.org/10.1007/s00227-002-0962-y. 
Xavier, J.C., Cherel, Y., 2009. Cephalopod beak guide for the Southern Ocean. British Antarctic Survey, Cambridge, UK.

Xavier, J.C., Cherel, Y., Allcock, L., Rosa, R., Sabirov, R.M., Blicher, M.E., Golikov, A.V., 2018. A review on the biodiversity, distribution and trophic role of cephalopods in the Arctic and Antarctic marine ecosystems under a changing ocean. Mar. Biol. 165. https://doi.org/10.1007/s00227-018-3352-9.

Xavier, J.C., Ferreira, S., Tavares, S., Santos, N., Mieiro, C.L., Trathan, P.N., Lourenço, S., Martinho, F., Steinke, D., Seco, J., Pereira, E., Pardal, M., Cherel, Y., $2016 a$. The significance of cephalopod beaks in marine ecology studies: Can we use beaks for DNA analyses and mercury contamination assessment? Mar. Pollut. Bull. 103, 220-226. https://doi.org/10.1016/j.marpolbul.2015.12.016.

Xavier, J.C., Raymond, B., Jones, D.C., Griffiths, H., 2016b. Biogeography of Cephalopods in the Southern Ocean Using Habitat Suitability Prediction Models. Ecosystems 19, 220-247. https://doi.org/10.1007/s10021-015-9926-1.

Young, J.W., Olson, R.J., Rodhouse, P.G.K., 2013. The role of squids in pelagic ecosystems: An overview. Deep Sea Res. II: Top. Stud. Oceanogr. 95, 3-6. https://doi.org/10.1016/j.dsr2.2013.05.008. 


\section{Supplementary material}

Annex 1. $\delta^{13} \mathrm{C}$ values in the analysed subsections obtained by Queirós et al. (2018).

\begin{tabular}{|c|c|c|c|c|c|}
\hline \multirow[t]{2}{*}{ Beak } & \multicolumn{5}{|c|}{$\delta^{13} \mathrm{C}$ values (\%) } \\
\hline & $\mathbf{R}$ & IV & III & II & I \\
\hline ML_U1 & & & & & \\
\hline ML_U2 & & -24.0 & -24.1 & -23.9 & -23.6 \\
\hline ML_U3 & & & & & \\
\hline ML_U4 & & & & & \\
\hline ML_U5 & -24.4 & -24.2 & -23.8 & -23.3 & -23.0 \\
\hline ML_U6 & & & & & \\
\hline ML_U7 & & & & & \\
\hline ML_U8 & & -24.9 & -25.2 & -24.8 & -23.0 \\
\hline ML_U9 & & & & & \\
\hline ML_U10 & & -26.3 & -25.3 & -25.2 & -25.0 \\
\hline & -24.4 & $\begin{array}{c}-24.5 \pm \\
0.9\end{array}$ & $\begin{array}{c}-24.6 \pm \\
0.7\end{array}$ & $\begin{array}{c}-24.3 \pm \\
0.7\end{array}$ & $\begin{array}{c}-23.2 \pm \\
0.3\end{array}$ \\
\hline
\end{tabular}

